\author{
Ye.D. Yehudina *, \\ O.V. Syniachenko **, \\ T.R. Polesova ${ }^{* *}$, \\ O.E. Chernyshova **, \\ M.V. Yermolaeva **
}

\section{DISTURBANCE OF THE MUSCOLOSKELETAL SYSTEM IN JUVENILE ANKYLOSING SPONDYLITIS AND DISEASE DEVELOPED IN THE ADULTHOOD (INVOLVEMENT OF SPINE AND SACROILIAC JOINTS)}

SE «Dnipropetrovsk medical academy of Health Ministry of Ukraine» *

Department of internal medicine 3

V. Vernadsky str., 9, Dnipro, 49044, Ukraine

e-mail: elizavetaegudina@gmail.com

Donetsk national medical university **

Department of internal medicine 1,

Pryvokzalna str., 27, Lyman, Donetsk region, 84404, Ukraine

ГУ «Днепропетровская медицинская академия МЗ Украины»" *

кафедра внутренней медицинь 3

(зав. - д. мед. н., дои. А.А. Ханюков)

ул. В. Вернадского, 9, Днепр, 49044, Украина

Донецкий национальный медицинский университет **

кафедра внутренней медиџины 1

(зав. - член-кор. НАМН Украины, д. мед. н., проф. О.В. Синяченко)

ул. Привокзальная, 27, Лиман, Донецькая область, 84404, Украина

Key words: ankylosing spondylitis, children, adults, spine, sacroiliac joints

Ключевые слова: спондилит анкилозирующий, дети, взрослье, позвоночник, крестиово-подвздошные сочленения

\begin{abstract}
Disturbance of the muscoloskeletal system in juvenile ankylosing spondylitis and disease developed in the adulthood (involvement of spine and sacroiliac joints). Yehudina Ye.D., Syniachenko O.V., Polesova T.R., Chernyshova O.E., Yermolaeva M.V. Background. Two forms of ankylosing spondylitis (AS) are distinguished: juvenile and adult, depending on debut age of the disease. The diagnosis of juvenile AS (JAS) is one of the most urgent problems in a pediatric rheumatology. The peculiarities of AS course that onsets in childhood and adulthood are manifested by differences in the nature of a spinal column disturbance. At the same time, the evolution of JAS in adulthood remains unexplored. The goals and objectives of research: to study clinical and X-ray symptoms of spondylopathy and sacroiliitis course, to assess their characteristics in the disease that onset in childhood and adulthood. Material and methods. 217 patients with AS (193 men and 24 women) with an average age of 38 years were examined. The fast-progressing course of the disease was detected in 21\% of cases, moderate and high degree of activity - in 79\% of cases, the II-III stage in 82\%, and polyarthritis - in 65\%. JAS was detected in 16\% of cases (all boys), among them the third stage occurred twice more likely than among the other patients. Results. The clinical and radiologic signs of spondylopathy and sacroiliitis are observed in 95\% and 97\% of the total number of AS cases, respectively, among all patients with JAS lumbago was detected 4,3 times more frequently, sciatic muscles hypotrophy7,8 times, "the string symptom" - 2,9 times", the calcification of the spinal cord - 2,3 times, whereas the prevalence of spinal column injury, the severity of cervico-spondylopathy and sacroiliitis among patients with the disease debut in the adulthood is significantly greater, and the involvement in the process of the lumbar and thoracic spine are detected correspondingly twice as often and by 19\%, occurrence of dorsalgia is 4 times as often, the limitation of body lateral bendover by 59\%, while there are ambiguous dispersion-correlation links with extraarticular (systemic) manifestations of the disease, and the high prevalence of a peripheral articular syndrome regarding spondylopathy in JAS is a negative prognosis sign, and for the remaining patients there are indices of the Lansbury index and the index of arthropathy progression. Conclusion: the onset of AS in adulthood is a risk factor for the severe course of spondylopathy.
\end{abstract}

Реферат. Поражение опорно-двигательного аппарата при ювенильном анкилозирующем спондилите и заболевании, начавшемся во взрослом возрасте (вовлечение позвоночника и крестцово-подвздошных сочленений). Егудина Е.Д., Синяченко О.В., Полесова Т.Р., Чернышева О.Е., Ермолаева М.В. Актуальность проблемы. Выделяют две формы анкилозирующего спондилита (АС) - детскую и взрослую, в зависимости от возраста дебюта заболевания. Проблема диагностики ювенильного АС (ЮАС) относится к наиболее актуальным в педиатрической ревматологии. Особенности течения АС, начавщегося в детском и взрослом возрасте, проявляются различиями в характере поражения позвоночного столба. При этом эволючия ЮАС во взрослом возрасте остается неизученной. Цель и задачи исследования: изучить у больных АС клиникорентгенологические признаки течения спондилопатии и сакроилеита, оценить их особенности при 
заболевании, начавшемся в детском и взрослом возрасте. Материал и методы. Обследованы 217 больных АС (193 мужчинь и 24 женщины) со средним возрастом 38 лет. Быстропрогрессирующее течение констатировано в 21\% наблюдений, умеренная и высокая степень активности - в 79\%, II-III стадия - в $82 \%$, полиартрит - в 65\%. ЮАС отмечен в 16\% случаев (все мальчики), у которых ІІІ стадия имела место вдвое чаще, чем у остальных паџиентов. Результатьл. Клинико-рентгенологические признаки спондилопатии и сакроилеита наблюдаются соответственно у 95\% и 97\% от общего числа случаев АС, при этом у всех больных ЮАС, у которых в 4,3 раза чаще выявляются люмбаго, в 7,8 раза гипотрофия седалищных мыши, в 2,9 раза «симптом тетивыл), в 2,3 раза кальцификация спинальных связок, тогда как распространенность поражения позвоночника, тяжесть цервикоспондилопатии и сакроилеита у пациентов с дебютом заболевания во взрослом возрасте достоверно большие, а вовлечение в процесс поясничного и грудного отделов позвоночника отмечается соответственно чаще вдвое и на 19\%, появление дорсалгий - в 4 раза, ограничение боковых наклонов туловища - на 59\%, при этом существуют неоднозначные дисперсионно-корреляционные связи с экстраартикулярными (системными) проявлениями болезни, а прогнознегативнылм признаком в отношении спондилопатии при ЮАС является большая распространенность периферического суставного синдрома, а у остальных больных - показатели индекса Лансбури и индекса прогрессирования артропатии. Выводы: начало АС во взрослом возрасте является фактором риска тяжелого течения спондилопатии.

Background. The prevalence of ankylosing spondylitis (AS) reaches $0.3 \%$ among the population [12, 16]. The modern concept divides this disease by the predominantly lesion of either the peripheral joints or the axial skeleton $[3,13,14]$. Meanwhile, two forms of AS are identified - juvenile (JAC) and adult (AAC), depending on the age of the disease debut $[7,9]$.

There are features of AS course that begans in childhood and adulthood [2, 5, 14], which, first of all, is manifested by the differences in the nature of the spinal column lesion $[1,6]$. At the same time there is a definite evolution of clinical manifestations of JAS in adult patients [8]. According to the literature, severe spine changes are rare in JAS [9], and involvement of the lumbar spine in the process, allegedly, is little typical for such patients $[4,6]$. A.Adrovic et al. [10] attributed the presence of asymptomatic sacroileitis and the absence of spondylopathy in the debut of JAS like the distinctive clinical signs in the contrast to AAC. It should be noted that the problem of clarifying the nature of spondylitis and sacroiliitis in the early stages of JAS is among the most relevant in pediatric rheumatology $[11,15]$.

The purpose and objectives of the study: to study the clinical and radiological signs of the spondylopathy and sacroiliitis course in patients with AS, to evaluate their characteristics in the disease that began in childhood and adulthood.

\section{MATERIAL AND METHODS}

217 AS patients aged 16 to 57 years old (an average of $37,7 \pm 0,64$ years) were under observation, $88,9 \%$ of men and $11,1 \%$ of women among them. The disease duration averaged 10,5 $\pm 0,39$ years. I degree of AS activity was established in $21,2 \%$ of cases, II - in $56,7 \%$ and III - in $22,1 \%$, I stage was noted in $18.4 \%$ of the surveyed patients, II - in $50,7 \%$ and III - in $30,9 \%$. Slowly progressive disease course occurred in $79,3 \%$ of cases, fast- progressing - in 20,7\%. The so-called "central form" of AS was diagnosed in 33,6\% of cases, "rhizomelic" - in 2,8\%, "peripheral" - in 5,1\%, "undifferentiated" $-58,5 \%$. Ophthalmopathy (uveitis), nervous system damage and visceral changes are established in $3 / 4$ of the patients' number.

Peripheral arthritis was determined in $66,4 \%$ of the patients number. The prevalence of articular syndrome (number of painful joints - NPJ) was $5,4 \pm 0,25$ r.u., its activity (DAS) $-4,0 \pm 0,10$ r.u., Lansbury index (LI) - $117,1 \pm 3,89$ points, progression of arthritis index (PAI) - 1,3 30,15 r.u. In the X-ray, sonography and densitometry studies, narrowing of the joint space was found in $38,7 \%$ of cases, subchondral sclerosis - in 12,9\%, osteocystis - in $25,4 \%$, epiphyseal osteoporosis - in $22,1 \%$, systemic osteoporosis - in $51,2 \%$, usuras of bone surface - in $10,6 \%$, intraarticular calcifications - in $11,5 \%$, changes in the horns of the knee joints menisci - in 18,0\%, Baker's cysts - $6,0 \%$, Shtaydie's bodies $-3,7 \%$, chondromous bodies $-9,2 \%$, Goff's bodies $-1,4 \%$. The Barnett-Nordin meta-carpal index was $0,43 \pm 0,004$ r.u., the bone mineral density index was $-1,49 \pm 0,055 \mathrm{SD}$. Enthesopathies were noted in $38,7 \%$ of the surveyed, tenosynovitis - in $28,6 \%$.

All patients were divided into two groups: the first (main) amounted to 35 (16.1\%) patients (all males) with onset of the disease under the age of 18 (JAS), and the others $182(83.9 \%)$, with AAS were included in the 2nd (control) group. The age of the main group representatives in the disease debut was $14,3 \pm 0,52$ years, and at the time of the examination $-24,9 \pm 0,83$ years, while in the control group it was $29,6 \pm 0,45$ years and $40,2 \pm 0,58$ years respectively. The duration of the disease in the 1 st and 2 nd groups did not differ. Both groups were approximately equal in the disease degree activity, but fast progressing course of the disease in AAS was 2,7 times more common. 
Patients have undergone X-ray ("Multix-Compact-Siemens", Germany) and ultrasound ("EnvisorPhilips", Netherlands and "ATL3500-Siemens", Germany) studies of peripheral joints, sacroiliac joints and spine, dual-energy X-ray absortiometry of the proximal femur ("Somazom-Emotion-6-Siemens", Germany) and magnetic resonance ("Gygoscan-Intera-Philips", the Netherlands) tomography of spondilopathy and sacroiliitis.

The serum levels of antibodies to cyclic citrullinated peptide ( $\mathrm{aCCP})$, the concentration of interleukin (IL) $1 \beta$ and tumor necrosis factor (TNF) were studied using the enzyme immunoassay (PR2100 Sanofi diagnostic pasteur, France), and the immunobiochemical analyzer "Olympus-AU-640 "(Japan), concentrations of C-reactive protein (CRP), fibrinogen (FG), circulating immune complexes (CIC), immunoglobulins (Ig) A, G and $\mathrm{M}$ were determined in blood serum. The aCCP values in serum of the examined AS patients were $22,2 \pm 8,41 \pm 0,57 \mathrm{U} / \mathrm{ml}$, $\mathrm{CRP}-12,0 \pm 5,89 \pm 0,40 \mathrm{mg} / \mathrm{l}, \mathrm{FG}-7,4 \pm 2,99 \pm 0,20 \mathrm{~g} / \mathrm{l}$, $\operatorname{IgA}-2,3 \pm 0,58 \pm 0,04 \mathrm{mmol} / \mathrm{L}, \quad \operatorname{IgG}-15,7 \pm 3,23 \pm$ $\pm 0,22 \mathrm{mmol} / 1, \mathrm{IgM}-2,0 \pm 0,62 \pm 0,04 \mathrm{mmol} / 1$, CIC $104,5 \pm 61,08 \pm 4,15$ r.u., IL1 $\beta-88,5 \pm 100,17 \pm 6,80 \mathrm{pg} / \mathrm{ml}$, TNF $-153,5 \pm 220,12 \pm 14,94 \mathrm{pg} / \mathrm{ml}$.

Statistical analysis of the research results was carried out by computer variations, nonparametric, correlation, regression, one- (ANOVA) and multivariate (ANOVA / MANOVA) variance analysis (Microsoft Excel and Statistica-Stat-Soft, USA). The mean values (M), their standard deviations (SD) and standard errors (m), Pearson parametric correlation coefficients ( $\mathrm{r}$ ) and nonparametric Kendall $(\tau)$, Brown-Forsythe dispersion criteria (BF), WilcoxonRao (WR), the multiple regression (R), Student (t) and McNamara-Fisher $\left(\chi^{2}\right)$, the reliability of statistical parameters $(\mathrm{p})$.

\section{RESULTS AND DISCUSSION}

Sacroiliitis was determined in all patients with AS, and signs of spondylopathy - in $94.9 \%$ of them. It should be noted that JAS and AAS differed a little from each other in spinal cord lesions, correspondingly being $100,0 \%$ and $94,0 \%$ of cases. This also referred to the severity of spondylopathy, which indices were $0,69 \pm 0,084$ points and $0,83 \pm 0,041$ points respectively in the 1 st and 2 nd groups. In the case of JAS, changes in the cervical spine $\left(\chi^{2}=6,83, p=0,009\right)$ were more frequent by $33 \%$, while in AAS, changes in lumbar region were twice as often $\left(\chi^{2}=33,33, p<0,001\right)$ and thoracic spine - by $19 \%\left(\chi^{2}=5,60, p=0,018\right)$, whereas in the sacroileitis incidence, both groups did not differ.

Vertebralgia was noted in $88,5 \%$ of the patients with AS, thoracalgia - in $54,8 \%$, dorsalgia - in
$50,2 \%$, pelvialgia - in $43,3 \%$, back muscle hypotrophy - in $36,4 \%$, restriction of the trunk lateral bendover - in 31,8\%, vertebrobasilar insufficiency in $30,9 \%$, "petitioner's pose" - in $13,4 \%$, soreness of the vertebrae spinous processes - in $10,1 \%$, "string symptom" and discoid of the back - in 7,8\%, lumbago - in 5,1\%, sciatic muscles hypothrophia - in $4,6 \%$. In the patients with JAS, dorsalgia was observed 4 times less frequent $\left(\chi^{2}=21,57, p<0,001\right)$ and the restriction of the trunk lateral bendover - by $59 \%$ $\left(\chi^{2}=5,90, p=0,015\right)$, but lumbago was found 4.3 times more often $\left(\chi^{2}=7,37, \mathrm{p}=0,007\right)$, sciatic muscles hypotrophy -7.8 times $\left(\chi^{2}=14,92, p<0,001\right)$ and "bowstrings symptom" -2.9 times $\left(\chi^{2}=5,01, p=0,025\right)$, which is reflected in Fig. 1-2.

Inflammatory, dishemic, mechanical and dysfixation character of painful spondylogenous syndromewas was established in 50,2\%, 24,9\%, 3,7\% and $21,2 \%$, respectively, of all patients with AS. The main and control groups differed a little from each other by the integral nature of pain, and also by the nature of vertebralgia.

Syndesmophytes were found in $89,9 \%$ of cases, spondylodyscitis - in $91,7 \%$, narrowing of the facet joint fissure - in $83,0 \%$, calcification of spinal ligamentum - in $13,4 \%$, ossification of intervertebral discs - in 30,9\%, ankylosis of facet joints - in 22,6\%, which is represented in Fig. 3. It has been established that only calcification of spinal ligaments in JAS occurred 2,3 times more often than with AAS $\left(\chi^{2}=5,50, p=0,019\right)$. The average severity of the cervical spine and sacroiliac joint lesion in patients with JAS was less by $25 \%$ of points $(t=6,18, p<0,001)$ and $17 \%$ points $(\mathrm{t}=2,35, \mathrm{p}=0,020)$, respectively.

According to Brown-Forsythe dispersion analysis, in JAS patients, the severity of spondylopathy is affected by seropositivity in aCCP $(\mathrm{BF}=5,08$, $\mathrm{p}=0,012)$ and the prevalence of peripheral articular syndrome $(B F=4,77, p=0,015)$, and in the control group - by character of the disease course $(\mathrm{BF}=6,85$, $\mathrm{p}=0,001)$, the presence of tendovaginitis $(\mathrm{BF}=4,03$, $\mathrm{p}=0,020)$, osteoporosis $(\mathrm{BF}=6,62, \mathrm{p}=0,002)$, uveitis $(\mathrm{BF}=9,71, \quad \mathrm{p}<0,001)$ and peripheral neuropathy $(\mathrm{BF}=3,14, \quad \mathrm{p}=0,046), \quad \mathrm{LI}$ parameters $\quad(\mathrm{BF}=3,17$, $\mathrm{p}=0,045)$ and PAI $(\mathrm{BF}=3,10, \mathrm{p}=0,048)$. In both JAS and AAS, the severity of spondylopathy rises proportionally to the increase in the patients' age and the disease duration, which is demonstrated by Pearson's correlation analysis $(r=+0,405, p=0,018$ and $\mathrm{r}=+0,378, \mathrm{p}<0.001 ; \mathrm{r}=+0,435, \mathrm{p}=0,010$ and $\mathrm{r}=+0,229, \mathrm{p}<0,001)$. It should be noted that in the main group there is a direct correlation between the degree of spinal cord lesion and the NPJ index $(\mathrm{r}=+0,659, \mathrm{p}<0,001)$, and in the control group - LI $(\mathrm{r}=+0,237, \mathrm{p}=0,003)$. Taking into account the 
performed dispersion-correlation analysis, it can be assumed that the risk factors for severe spondylopathy

in JAS is NPJ $>10$ r.u., and for AAS, LI $>170$ points $(>\mathrm{M}+\mathrm{SD}$ of the corresponding groups of patients).

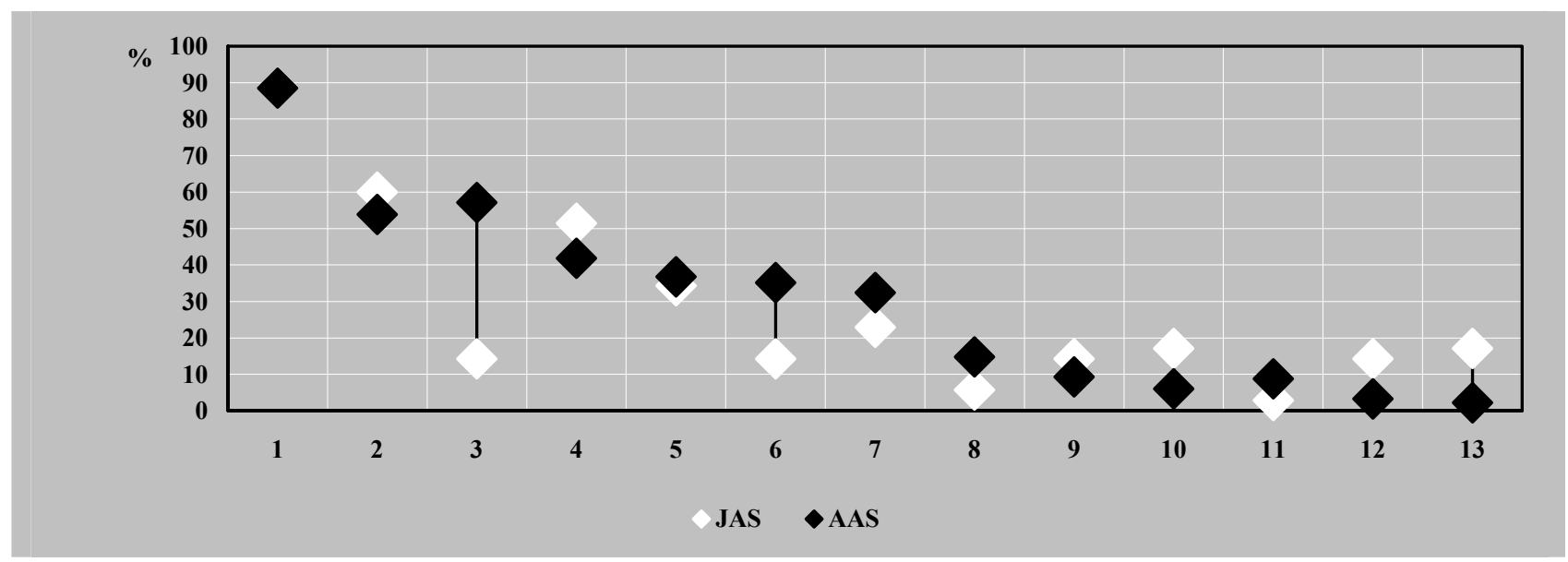

Fig. 1. Frequency of separate clinical signs in patients with JAS and AAS

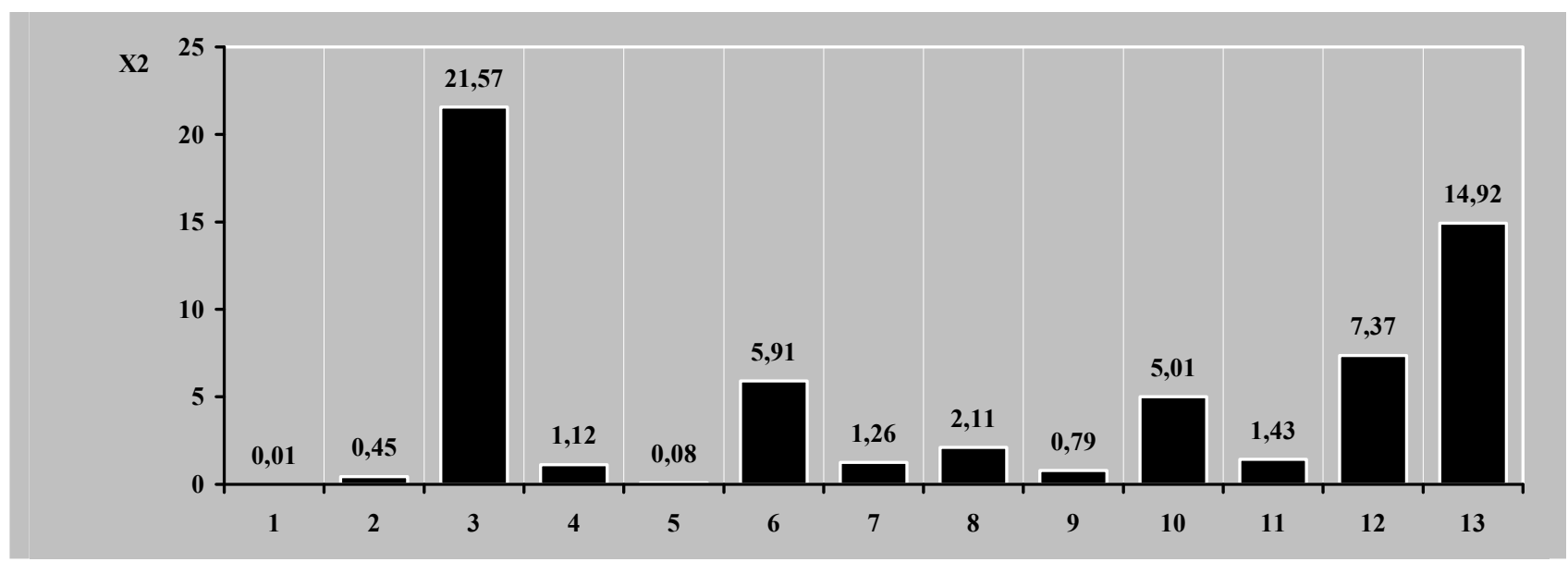

1 - vertebralgia, 2 - thoracalgia, 3 - dorsalgia, 4 - pelvialgia, 5 - back rectus muscles hypotrophy, 6 - restriction of the trunk lateral bendover, 7 vertebrobasilar insufficiency, 8 - "pose of the petitioner", 9 - soreness of the vertebrae spinous processes, 10 - "symptom of the bowstring", 11 discoid of the back, 12 - lumbago, 13 - sciatic muscles hypothrophia

Fig. 2. Differences in patients with JAS and AAS

The presence of coxitis $(\mathrm{BF}=3,43, \mathrm{p}=0,045)$ exerts a dispersion influence on severity of the spine injury in the main group patients, and involvement in the pathological process of the metatarsophalangeal joints $(B F=3,76, p=0,025)-$ in the control group. Among all patients with AS, the degree of spondylopathy depends on the aCCP parameters $(\mathrm{BF}=25,79, \mathrm{p}<0,001), \mathrm{FG}(\mathrm{BF}=3,31, \mathrm{p}=0,039)$ and $\mathrm{CIC}(\mathrm{BF}=3,84, \mathrm{p}=0,023)$.

Attention was paid to Kendall's contradictory correlation relations between the severity of the spine lesion and some immunoinflammatory indicators of blood serum. So, if there are direct relations with the levels of aCCP $(\tau=+0,387, p=0,022)$ and $\operatorname{IgM}(\tau=+0,366, p=0,030)$ in JAS, then CRP concentrations $(\tau=+0,178, \mathrm{p}=0,016), \operatorname{IgG}(\tau=+0,208$, $\mathrm{p}=0,005)$ and IL1 $(\tau=+0,148, \mathrm{p}=0,048)-$ in AAS.
It must be emphasized, as Wilcoxon-Rao multifactor analysis demonstrated, the severity of spondylopathy has a significant influence $(p<0.001)$ on other integral signs of the disease both in the main $(\mathrm{WR}=8,06)$ and control (WR=5,21) groups, and there are direct regression relations with the severity of immune-inflammatory disorders $(\mathrm{R}=+1,96$, $\mathrm{p}=0,045$ and $\mathrm{R}=+7,60, \mathrm{p}<0,001$, respectively).

In JAS, direct Kendall correlations between separate parameters of spine and peripheral joint lesions are established, in particular, the ratios of "syndesmophytes $\leftrightarrow$ subchondral sclerosis $(\tau=+0,240$, $\mathrm{p}=0,042)$, "spinal cord calcification $\leftrightarrow$ arthrocalcinates" $(\tau=+0,494, p<0,001)$, "narrowing of the facet joint fissure $\leftrightarrow$ chondromous intra-articular bodies" ( $\tau=+0,251, p=0,035$ ), "ossification of the intervertebral disks $\leftrightarrow$ osteocystosis" $(\tau=+0,359, \mathrm{p}=0,002)$. 


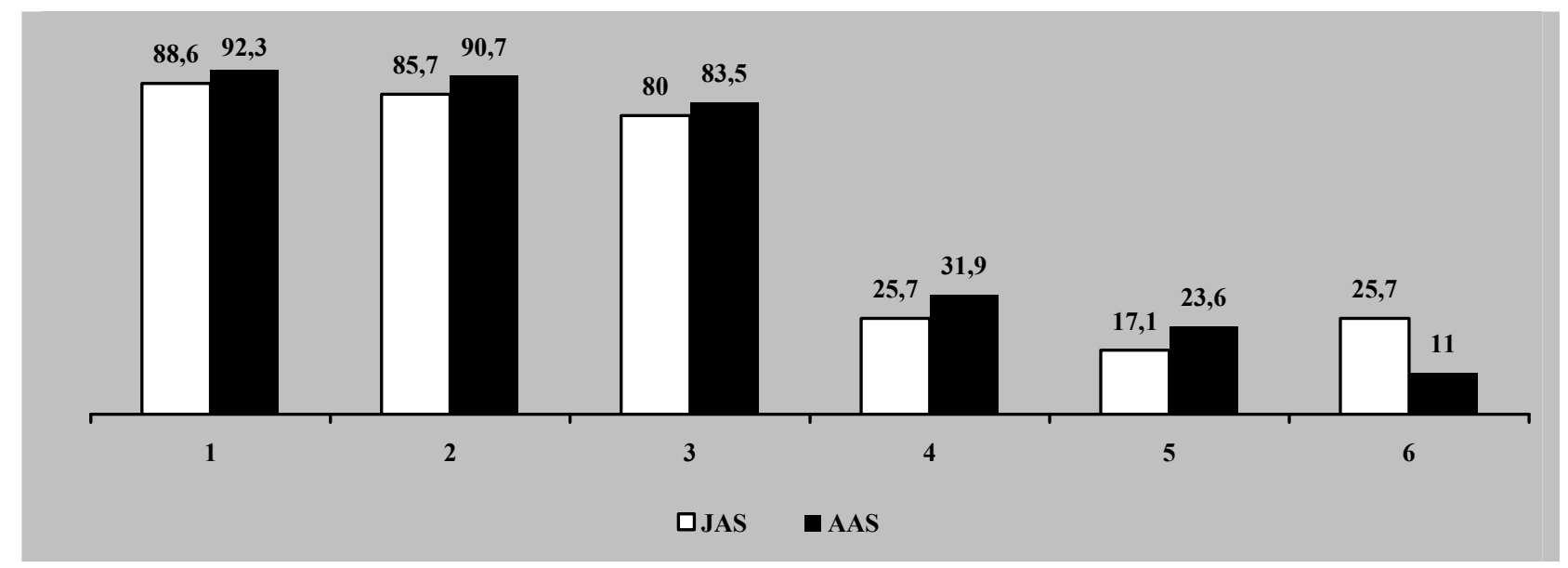

1 - spondylodiscitis, 2 - syndesmophytes, 3 - narrowing of the arcuate articulations, 4 - ossification of the intervertebral disks, 5 - ankylosis of the facet joints, 6 - calcification of the spinal cord

Fig. 3. The frequency of separate signs of spondylopathy in patients with JAS and AAS (\%)

\section{CONCLUSIONS}

1. Clinical and radiologic signs of spondylopathy and sacroiliitis are observed in $95 \%$ and $97 \%$ of the total number of AS patients, respectively, while in all patients with JAS

2. Lumbago is detected 4,3 times more often in JAS than in cases of AAS, hypotrophy of sciatic muscles - 7,8 times, "symptom of the bowstring" 2,9 times, calcification of spinal ligaments $-2,3$ times, while the prevalence of spine lesions, severity of cervico-spondylopathy and sacroiliitis are significantly greater in patients with debut of the disease in adulthood.

3. Involvement of the lumbar and thoracic spine in the process in patients with AAS is correspondingly more often by 2 times and by $19 \%$, the appearance of dorsalgia - by 4 times, the restriction of the trunk lateral bendover - by $59 \%$, while there are controversal dispersion-correlation links with extraarticular (systemic) manifestations of the disease.

4. Negative prognosis sign of spondylopathy in JAS is the high prevalence of peripheral articular syndrome, and in AAS - LI and PAI indices.

5. In the future it will be useful to predict the course of spine and sacroiliac joint lesions in AS patients with the disease onset in childhood and adulthood for subsequent timely rehabilitation activities, and the assessment of spondylopathy and sacroiliitis components nature may have practical importance as risk factors for separate extraarticular signs of the disease.

Conflict of interest. The authors declare that there is no conflict of interest, while the authors have not received financial support for research from individuals and organizations, fees and other forms of rewards.

\section{REFERENCES}

1. Li YH, Zhang XY, Li QH, Zheng DH, Dai L. Andersson lesion in ankylosing spondylitis: a clinical study of 14 cases. Zhonghua Yi Xue Za Zhi. 2017;97(7):51721. doi: 10.3760/cma.j.issn.0376-2491.2017.07.009

2. Berard RA, Laxer RM. Paediatric rheumatology: A disease activity index for juvenile SpA-a welcome addition. Nat Rev Rheumatol 2014;10(11):642-4. doi: 10.1038/nrrheum.2014.150

3. Brown M, Bradbury LA. New approaches in ankylosing spondylitis. Med J Aust 2017;206(5):192-4.

4. Gazeau P, Cornec D, Timsit MA, Dougados M, Saraux A. Classification criteria versus physician's opinion for considering a patient with inflammatory back pain as suffering from spondyloarthritis. Joint Bone Spine. 2017;16(2):162-8. doi: $10.1016 /$ j.jbspin.2017.01.010
5. Mou Y, Zhang P, Li Q, Lin Z, Liao Z, Wei Q, Gu J. Clinical features in juvenile-onset ankylosing spondylitis patients carrying different B27 subtypes. Biomed Res Int. 2015;20(15):594878. doi: 10.1155/2015/594878

6. Kim TJ, Shin JH, Sung IH, Lee S, Song Y, Kim TH. Comparison on radiographic progression for 5 years between juvenile onset ankylosing spondylitis and adult onset ankylosing spondylitis: an observational study of the Korean spondyloarthropathy registry (OSKAR) data. Clin Exp Rheumatol. 2016;34(4):668-72.

7. Conway R, O'Shea FD. Juvenile versus adultonset ankylosing spondylitis: are we comparing apples and oranges? J Rheumatol. 2012;39(5):887-9. doi: 10.3899/jrheum. 120164

8. Barber CE, Marshall DA, Mosher DP, Akhavan P, Tucker L, Houghton K, Batthish M, Levy DM, 
Schmeling H, Ellsworth J, Tibollo H, Grant S, Khodyakov D, Lacaille D. Development of system-level performance measures for evaluation of models of care for inflammatory arthritis in Canada. $\mathrm{J}$ Rheumatol 2016;43(3):530-40. doi: 10.3899/jrheum.150839

9. Jadon DR, Ramanan AV, Sengupta R. Juvenile versus adult-onset ankylosing spondylitis - clinical, radiographic, and social outcomes. a systematic review. J Rheumatol. 2013;40(11):1797-805. doi: 10.3899/jrheum.130542

10. Adrovic A, Barut K, Sahin S, Kasapcopur O. Juvenile spondyloarthropathies. Curr Rheumatol Rep 2016;18(8):55-65. doi: 10.1007/s11926-016-0603-y

11. Lin C, Milojevic D. Diagnosis and treatment juvenile spondyloarthropathy and related diseases. Pediatr Ann. 2012;41(11):172-8. doi: 10.3928/00904481-20121022-11

12. Usenbo A, Kramer V, Young T, Musekiwa A. Prevalence of arthritis in Africa: A systematic review and meta-analysis. PLoS One. 2015;10(8):0133858. doi: 10.1371/journal.pone.0133858
13. Sieper J, Poddubnyy D. Axial spondyloarthritis. Lancet. 2017;19(1):155-65. doi: 10.1016/S01406736(16)31591-4

14. Strand V, Singh JA. Evaluation and management of the patient with suspected inflammatory spine disease. Mayo Clin Proc. 2017;20(2);214-8. doi: 10.1016/j.mayocp.2016.12.008

15. Tse SM, Laxer RM. New advances in juvenile spondyloarthritis. Nat Rev Rheumatol. 2012;8(5):269-79. doi: 10.1038/nrrheum.2012.37

16. Rohekar S, Chan J, Tse SM, Haroon N, Chandran V, Bessette L, Mosher D, Flanagan C, Keen KJ, Adams K. 2014 Update of the Canadian Rheumatology Association/spondyloarthritis research consortium of Canada treatment recommendations for the management of spondyloarthritis. Part I: principles of the management of spondyloarthritis in Canada. J Rheumatol. 2015;42(4):654-64. doi: 10.3899/jrheum. 141000

\section{СПИСОК ЛИТЕРАТУРЫ}

1. Andersson lesion in ankylosing spondylitis: a clinical study of 14 cases / Y. H. Li, X. Y. Zhang, O. H. Li [et al.] // Zhonghua Yi Xue Za Zhi. - 2017. - Vol. 97, N 7. - P. 517-521.

2. Berard R. A. Paediatric rheumatology: A disease activity index for juvenile SpA-a welcome addition / R.A. Berard, R. M. Laxer // Nat. Rev. Rheumatol. - 2014. - Vol. 10, N 11. - P. 642-644.

3. Brown M. New approaches in ankylosing spondylitis / M. Brown, L.A. Bradbury // Med. J. Aust. 2017. - Vol. 206, N 5. - P. 192-194.

4. Classification criteria versus physician's opinion for considering a patient with inflammatory back pain as suffering from spondyloarthritis / P. Gazeau, D. Cornec, M.A. Timsit [et al.] // Joint Bone Spine. - 2017. Vol. 16, N 2. - P. 162-168.

5. Clinical features in juvenile-onset ankylosing spondylitis patients carrying different B27 subtypes / Y. ou, P. Zhang, Q. Li [et al.] // Biomed. Res. Int. - 2015. - Vol. 20, N 15. - E. 594878.

6. Comparison on radiographic progression for 5 years between juvenile onset ankylosing spondylitis and adult onset ankylosing spondylitis: an observational study of the Korean spondyloarthropathy registry (OSKAR) data / T.J. Kim, J. H. Shin, I. H. Sung [et al.] // Clin. Exp. Rheumatol. - 2016. - Vol. 34, N 4. - P. 668-672.

7. Conway R. Juvenile versus adult-onset ankylosing spondylitis: are we comparing apples and oranges? / R. Conway, F. D. O'Shea // J. Rheumatol. - 2012. Vol. 39, N 5. - P. 887-889.

8. Development of system-level performance measures for evaluation of models of care for inflammatory arthritis in Canada / C.E. Barber, D.A. Marshall,
D.P. Mosher [et al.] // J. Rheumatol. - 2016. - Vol. 43, N 3. - P. 530-540.

9. Jadon D. R. Juvenile versus adult-onset ankylosing spondylitis - clinical, radiographic, and social outcomes. a systematic review / D.R. Jadon, A.V. Ramanan, R. Sengupta // J. Rheumatol. - 2013. - Vol. 40, N 11. - P. 1797-1805.

10. Juvenile spondyloarthropathies / A. Adrovic, K. Barut, S. Sahin, O. Kasapcopur // Curr. Rheumatol. Rep. - 2016. - Vol. 18, N 8. - P. 55-65.

11. Lin C. Diagnosis and treatment of juvenile spondyloarthropathy and related diseases / C. Lin, D. Milojevic // Pediatr. Ann. - 2012. - Vol. 41, N 11. - P. 172-178.

12. Prevalence of arthritis in Africa: A systematic review and meta-analysis / A. Usenbo, V. Kramer, T. Young, A. Musekiwa // PLoS One. - 2015. - Vol. 10, N 8. - E. 0133858.

13. Sieper J. Axial spondyloarthritis / J. Sieper, D. Poddubnyy // Lancet. - 2017. - Vol. 19, N 1. - P. 155-165.

14. Strand V. Evaluation and management of the patient with suspected inflammatory spine disease / V. Strand, J.A. Singh // Mayo Clin. Proc. - 2017. Vol. 20, N 2. - P. 214218.

15. Tse S.M. New advances in juvenile spondyloarthritis / S. M. Tse, R. M. Laxer // Nat. Rev. Rheumatol. - 2012. - Vol. 8, N 5. - P. 269-279.

16. 2014 Update of the Canadian Rheumatology Association/spondyloarthritis research consortium of Canada treatment recommendations for the management of spondyloarthritis. Part I: principles of the management of spondyloarthritis in Canada / S. Rohekar, J. Chan, S.M. Tse [et al.] // J. Rheumatol. - 2015. - Vol. 42, N 4. P. 654-664. 